\title{
Blended Learning to Improve Learning Outcomes in Digital Electronics Courses
}

\author{
Dewi Dewantara, Mustika Wati, Misbah, Saiyidah Mahtari, Surya Haryandi \\ Physics Education \\ Universitas Lambung Mangkurat \\ Banjarmasin, Indonesia \\ dewantarafisika@gmail.com
}

\begin{abstract}
This article focuses to describe the effectiveness of blended learning in digital electronics courses. This research is descriptive analysis research. The subjects of this study were 48 students of physics education FKIP Lambung Mangkurat University. The effectiveness of the implementation of blended learning is viewed from the results of student cognitive learning, using learning outcomes tests. Data were analyzed in the following ways, (1) analyzing descriptively from the average results of the learning outcomes test, (2) analyzing by using paired t-test to describe the significance of differences in student learning outcomes, (3) analyzing with n-gain test to find out the level of effectiveness in improving student learning outcomes. The results showed that the average of the pretest was 14.38 and the average of the posttest was 79.22. The sig-2-tailed result from the paired t-test is less than 0.05 so there is a significant difference between pretest and posttest. The $\mathbf{N}$-gain score is 0.76 which means this has a high category. The conclusion is the implementation of blended learning in digital electronics courses is effective in improving student learning outcomes.
\end{abstract}

Keywords: blended learning, learning outcomes

\section{INTRODUCTION}

The Industrial Revolution Era 4.0 was marked by digitalization and automation in various aspects of human life including education and learning [1]. Education is an indicator of the glory of the nation where one important element in education is learning [2]. The demand of the times is for education to go in harmony with technology [3]. Technological development is accompanied by the use of technology results in the learning process, which requires humans to participate in following [4].

Digital electronics is a subject that studies about Digital Circuits and Systems, Number Systems and Code Systems, Basic Logic Gates and Boolean Algebra, Combined Logic Circuits, Combined Logic in ICs, Sequence Logic Circuits, and Enumerators and Registers. Many materials sometimes cannot be explained maximally in face-to-face classes so that there is a lack of understanding of students towards the material being taught [5]. In addition, the low learning outcomes can be due to less effective learning, especially lack of class hours, so it must be anticipated in advance [6], [7]. In fact, in the current era, computer and network technology is available but its utilization is still not optimal [8].

The selection of learning methods used by lecturers is strongly influenced by the nature of the material being taught, also influenced by the objectives to be achieved in the teaching and the level of student ability [4]. Related to the role of educators as learning agents, an educator is required to be able to provide optimal learning by using a variety of learning methods and models that are tailored to the characteristics of students [9]. In the lecture process, it takes a learning pattern that integrates technology in learning so as to enable students to study [3]. Blended learning has a high potential to be applied in higher education [10], [11].

Blended learning can be one solution as an answer where education must begin to follow the development of science and technology [12]. Blended learning is a combination of face-toface and online learning to maximize the learning process [13]. Blended learning is a term derived from English, which consists of two syllables, blended and learning. Blend is a mixture which means there are various kinds of learning patterns used. While learning means learning. So that it can be interpreted as a merging or mixing aspect in learning, which can consist of two or more strategies or media that can be used [4]. Blended learning is seen as being able to compensate for these demands because this learning model is not the same as distance learning (e-learning with distance learning approach) nor is it like face-to-face learning alone [14].

In digital electronics lectures in the previous year, there had never been blended learning. This article focuses to describe the effectiveness of blended learning in digital electronics courses to improve learning outcomes.

\section{METHOD}

This type of study was a descriptive analysis study. This study focused on analyzing descriptively the quality of implementation of blended learning in digital electronics learning seen from its effects on student learning outcomes and student responses. The subjects of this study were 48 students of FKIP physics education at Lambung Mangkurat University who joined digital electronics courses in 2018/2019. The effectiveness of the implementation of blended learning is 
viewed from the results of student cognitive learning, using learning outcomes tests. Data were analyzed in the following ways, (1) analyzing descriptively from the average results of the learning outcomes test, (2) analyzing by using paired t-test to describe the significance of differences in student learning outcomes [15], (3) analyzing with n-gain test to find out the level of effectiveness in improving student learning outcomes [16].

\section{RESULTS AND DISCUSSION}

Blended learning is a learning method that combines conventional based learning with multimedia based or elearning based [4]. Blended learning is applied in digital electronics lectures to match the characteristics of digital electronic materials and the characteristics of students. The following is a comparison chart of student pretest and posttest results.

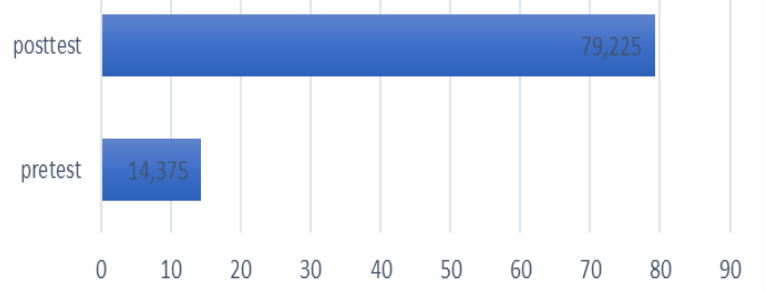

Fig. 1. Result of pretest and posttest

The results of the pretest and posttest were then tested for normality and homogeneity which showed that the data were normally distributed and the variants were homogeneous. Then, this data is tested for the significance of the difference using the paired t-test. Table 1 shows the results of the test. Sig value (2-tailed) shows a number below 0.05 .

TABLE I. RESULT OF PAIRED T-TEST

\begin{tabular}{|c|c|c|c|c|}
\hline \multicolumn{2}{|c|}{} & T & df & $\begin{array}{c}\text { Sig. } \\
\text { (2-tailed) }\end{array}$ \\
\hline Pair 1 & $\begin{array}{c}\text { posttest }- \\
\text { pretest }\end{array}$ & 205,585 & 47 &, 000 \\
\hline
\end{tabular}

The effectiveness of the application of blended learning is tested using the $\mathrm{N}$-gain test to determine its effectiveness category. The N-Gain test result is 0.76 . Thus these results are categorized as high. The application of blended learning is effective in increasing student learning outcomes in the high category. This result is in accordance with previous research which shows that the application of blended learning model has an effect on student learning outcomes [4], [13], [17]-[20].

The use of instructional media that is appropriate to offset the rapid development of technology is to utilize mobile devices in teaching and learning activities, such as smartphones, laptops, gadgets, and others. [8]. Blended learning combines various teaching methods and strategies that utilize virtual technology [13]. Blended Learning has advantages including to increase the effectiveness of learning; Expanding the reach of learning; time and cost efficiency; and improve final performance [1]. Blended Learning is considered to make learning more meaningful [11], [21].

The application of blended learning in higher education is currently very effective, because blended learning provides innovation in the learning process [2]. Blended learning is a learning strategy that can contribute to student competencies [10]. Blended Learning combines flexible distance learning and conventional face-to-face learning where teachers can provide motivation and emotional closeness to their students [14]. Students are also the key to successfully implementing blended learning because blended learning requires students to be prepared to learn independently [22]. E-learning learning requires that students learn independently according to the instructions provided by the teacher on the online platform [18, 22]. The involvement of students in teaching and learning activities will increase, as well as competition between students will be seen and recorded clearly so as to encourage students to be more willing to engage in discussion forums [20].

The main target of using Blended Learning is the use of information and communication technology in order to help students understand and apply the concepts taught [24]. Blended learning means the merging of various characteristics of the advantages of internet-based learning (e-learning online), multimedia-based (e-learning offline) and the use of mobile technology with face-to-face learning in order to increase competence, creativity and the power of innovation of students and students become more character [10]. Blended learning can also provide a flexible time frame, so students can be more independent and can improve their learning abilities at their own pace [2].

In blended learning, students are required to actively interact with online media so they must have time to study independently outside the classroom [9]. Blended learning aims to optimize learning activities for the better, and facilitate the characteristics and independence of student learning [2]. Blended Learning has advantages including to increase the effectiveness of learning; Expanding the reach of learning; time and cost efficiency; and improve final performance [1]. Blended learning is seen as being able to compensate for these demands because this learning model is not the same as distance learning (e-learning with distance learning approach) nor is it like face-to-face learning alone [14].

Blended learning assisted learning is not only applied during the face-to-face learning process in the classroom but can also be applied when there are activities outside the faceto-face with internet access. [13]. Based on this, technological developments have brought humans to a space that is able to provide convenience in their daily lives [5]. Information about teaching methods, teaching media, and learning resources can make learning activities more interesting, not monotonous so that it can provide motivation for students to continue listening in learning activities [22]. Learning Management System becomes interesting learning and no longer just listening to the description of the teacher alone, but students can do other activities such as observing, doing and demonstrating and also students can make designs and search for material with their own efforts [25]. 
Learning activities are efforts to create an atmosphere and service to the abilities, potentials, interests, and methods, as well as assessment and steps in teaching will be related to learning activities to achieve goals [12]. Online learning prioritizes interaction between students and students or teachers in online discussions conducted by students in small groups or online discussions with all students in large groups so as to give students the opportunity to apply concepts that have been obtained with unlimited time in class meetings [13]. The rapid development of electronic-based learning resources now allows students to be able to learn anytime and anywhere [14].

In this digital age by utilizing technology and communication students get information that is needed to help to learn [22]. Blended learning is a learning with a technological approach that combines learning resources face to face with the instructor as well as those contained in computer media and cell phones. The essence of Blended Learning is to increase interaction between students and lecturers and increase student responsibility for their learning experience [21]. In its application, blended learning requires a learning management system such as e-learning for better classroom management and to provide more effective experiences for students [24].

\section{CONCLUSION}

The conclusion is that the implementation of blended learning in digital electronics courses is effective in improving student learning outcomes. This can be seen from the difference in the average pretest and posttest which is then paired t-test, which shows that there is a significant influence on student learning outcomes. Likewise, the results of the $\mathrm{N}$ gain test show that the effectiveness of the category is high. Seeing this result, blended learning can be tried in other courses in order to improve learning outcomes. A further study is needed, more specifically related to the implementation of blended learning to improve students' abilities and skills specifically and in detail.

\section{REFERENCES}

[1] A. goleman daniel, boyatzis Richard, and Mckee, "Workshop Pengembangan Blended Learning Berbasis Google Classroom (Gc) Sebagai Solusi Pembelajaran Dan Penelitian Tindakan Kelas (Ptk)," in J. Chem. Inf. Model., vol. 53, no. 9, 2019, pp. 1689-1699.

[2] T. Al Aslamiyah, P. Setyosari, and H. Praherdhiono, "Blended Learning dan Kemandirian Belajar Mahasiswa Teknologi Pendidikan," in J. Kaji. Teknol. Pendidik., vol. 2, no. 2, 2019.

[3] Hasmunarti, A. Bahri, and I. S. Idris, "Analisis kebutuhan pengembangan blended learning terintegrasi strategi PBLRQA (Problem-Based Learning and Reading, Questioning \& Answering) pada pembelajaran biologi," in Biol. Teach. Learn., vol. 1, no. 2, 2018.

[4] L. H. Siregar, "Penerapan metode pembelajaran blended learning terhadap hasil belajar mahasiswa di institut pendidikan Tapanuli Selatan Padangsidimpuan," in J. Educ. Dev. Inst., vol. 7, no. 1, 2019.

[5] I. P. Darmika, G. Gunatama, and I. M. Sutama, "Penggunaan ELearning Dalam Pembelajaran Bahasa Indonesia Di Sma Negeri Bali Mandara," in J. Pendidik. Bhs. dan Sastra Indones. Undiksha, vol. 8, no. 2, 2019.

[6] F. Noviyanti, I. Sugiharta, and F. Farida, "Analisis Kemampuan Pemecahan Masalah Matematis: Dampak Blended Learning
Menggunakan Edmodo," in Desimal J. Mat., vol. 2, no. 2, 2019.

[7] D. Dewantara, "Perbedaan Kemampuan Analisis Mahasiswa Antara Pembelajaran Berbantuan Schoology dan Edmodo Pada Mata Kuliah Fisika Biologi," Prism. Sains J. Pengkaj. Ilmu dan Pembelajaran Mat. dan IPA IKIP Mataram, vol. 6, no. April, 2018.

[8] M. Fadloli, E. Kusumo, and Kasmui, "Pengembangan Model Pembelajaran Blended Learning Berbasis Edmodo untuk Pembelajaran Kimia yang Efektif," in Chem. Educ., vol. 8, no. 1, 2019.

[9] Y. R. Kusumaningrum and S. Sundari, "Efektivitas metode blended learning terhadap peningkatan kognitif dan motivasi belajar peserta didik prodi s1 keperawatandi Stikes An Nur Purwodadi," in Shine Cahaya Dunia S1 Keperawatan, vol. 4, no. 1, 2017.

[10] M. Palennari and F. Daud, "Pengembangan strategi blended-learning pada perkuliahan biologi dasar," in Indones. J. Educ. Stud., vol. 22, no. $1,2018$.

[11] D. Dewantara, M. Misbah, and M. Wati, "The Implementation of Blended Learning in analog electronic learning," in J. Phys. Conf. Ser., vol. 1422 , no. $012002,2019$.

[12] I. D. Kristiono, W. D. Dwiyogo, and I. Hariadi, "Pembelajaran Ilmu Gizi Olahraga Berbasis Blended Learning pada Mahasiswa Pendidikan Jasmani, Kesehatan, dan Rekreasi," in J. Pendidik. Teor. Penelitian, dan Pengemb., vol. 4, no. 2, 2019.

[13] S. O. Asmi, S. Wonorahardjo, and H. R. Widarti, "Model Problem Based Learning Berbantuan Blended Learning terhadap Kesadaran Metakognitif Mahasiswa pada Materi Spektroskopi Atom," in $J$. Pendidik. Teor. Penelitian, dan Pengemb., vol. 4, no. 6, 2019.

[14] M. L. Hidayat and R B Utami, "Pengukuran Kesiapan Penerapan Pembelajaran Blended Learning Di Sekolah Menengah Dengan Kelas Bakat," in Pros. Semin. Nas. Geotik 2019, 2019.

[15] J. . Creswell, Educational Research Planning, Conducting, and Evaluating Quantitative and Qualitative Research Fourth Edition. Boston: Pearson, 2012.

[16] R. R. Hake, "Interactive-Engagement versus Traditional Methods: A Six-Thousand-Student Survey of Mechanics Test Data for Introductory Physics Courses," in Am. J. Phys., vol. 66, 1998.

[17] N. Muhson, "Penerapan Blended Learning dalam Meningkatkan Hasil Belajar PAI Materi Sejarah Bani Umaiyah Kelas Viii Smpn 3 Pontianak," in Sos. Horiz. J. Pendidik. Sos., vol. 6, no. 1, 2019.

[18] N. Ali and G. A. Y. P. Adistana, "Penerapan Blended Learning Menggunakan Aplikasi Google Classroom Pada Kompetensi Dasar Mempresentasikan Jenis-Jenis Alat Berat Pada Pekerjaan Konstruksi," in J. Kaji. Pendidik. Tek. Bangunan, vol. 5, no. 2, 2019.

[19] E. D. Pitaloka and S. Suyanto, "Keefektifan Blended - Problem Based Learning terhadap Pemecahan Masalah pada Materi Ekologi," in $J$. Pendidik., vol. 4, no. 5, 2019.

[20] D. . Purwitasari, I. W. . Astawa, and I. G. . Sudiarta, "Penerapan Blended Learning Berbantuan Schoology Untuk Meningkatkan Keaktifan Dan Prestasi Belajar Matematika Siswa Kelas Viii a1 Smp Negeri 6 Singaraja," in J. Pendidik. dan Pembelajaran Mat. Indones., vol. 8, no. 2, 2019.

[21] R. Yusny and G. I. Yasa, "Mengembangkan (Pembelajaran) Blended Learning Dengan Sistem Lingkungan Pembelajaran Virtual (Vle) Di Ptkin," in J. Ilm. Islam Futur., vol. 19, no. 1, 2019.

[22] A. W. U. A. D. R. Sulthoni, "Faktor-Faktor Yang Berpengaruh Terhadap Implementasi Blended Learning Di Jurusan Teknologi Pendidikan Universitas Negeri Malang," in J. Kaji. Teknol. Pendidik., vol. 2, no. 1, 2019.

[23] Misbah, W. aji Pratama, Srihartini, and D. Dewantara, "Pengembangan e-learing berbasis schoology pada materi impuls dan momentum untuk melatihkan literasi digital," in Pancasakti Sci. Educ. J., vol. 3, no. 1, 2018.

[24] H. Hamid and I. Aras, "Pengembangan pembelajaran berbasis blended learning pada mata kuliah research statistics di jurusan pendidkan bahasa inggris universitas borneo tarakan," in Edukasia, vol. 6, no. 1, 2019.

[25] L. Ichnatun, M. Qaddafi, and A. Ferawati, "Penerapan Model Pembelajaran Blended Learing Berbantuan Learning Manajemen System Edmodo Terhadap Hasil Belajar," in J. Pendidik. Fis., vol. 7, no. 2, 2019. 